\title{
SUSPENSION OF LANDLORD AND TENANT RULES DURING HOUSING SHORTAGE
}

In a recent New York case, Johnson v. Pemberton, ${ }^{x}$ plaintiff landlord sued to recover possession of an apartment on which the payment of rent was four months in arrears. It appeared that, although a fire had rendered the apartment virtually uninhabitable, the tenant, unable to find other quarters because of the housing shortage, was forced to remain and shift for himself as best he could. Under the law of New York ${ }^{2}$ the tenant has the option, when his apartment has been extensively damaged, either to quit and surrender the premises, thereby terminating his duty to pay rent, or to remain in possession. However, so long as he retains possession, he may not escape the duty to pay his rent in full. Judge Quinn of the Municipal Court of New York City decided that under federal rent laws and regulations ${ }^{3}$ any decrease in essential services provided by the landlord automatically lowers the amount of rent which he may demand and receive. Thus, the plaintiff could recover only such an amount as the Housing Expeditor might determine to have been the maximum rent, based upon the decreased living space and services. 4

The effect of the decision is to suspend the operation of New York Real Property Law in regard to the defense of "constructive eviction" when that law is in conflict with emergency rent laws and regulations. ${ }^{5}$ The opinion, moreover, evidences the disposition of the judge to treat at least some of the traditional rules of landlord and tenant as too harsh to be enforced in times of a housing shortage so severe as to amount to a public emergency. ${ }^{6}$

This view is also shared by other courts. It was stated, for example, in Park East Land Corp. v. Finkelstein, 7

whether or no strict adherence to technical concepts of landlord and tenant law would have justified eviction under ordinary conditions in ordinary times, need not detain or concern us.... [I]n the housing field at least, these are not ordinary times. ...

${ }^{1} 97$ N.Y. Misc. 739, 97 N.Y.S. 2 d 153 (N.Y. Munic. Ct., I950).

${ }^{2}$ N.Y. Real Prop. Law $\$ 223$, enacting what was formerly the common-law rule. Smith v. Kerr, 108 N.Y. 3I, I5 N.E. 70 (1888); Plymouth Estate, Inc. v. Keery, x9o N.Y. Misc. 8I9, 76 N.Y.S. $2 d 89$ (1947). But cf. Majen Realty Corp. v. Glotzer, 6r N.Y.S. 2d I95 (N.Y. Munic. Ct., I946). See note 26 infra.

3 Housing Act of 1947,60 Stat. I93 (I946), as amended, 5o U.S.C.A. $\$$ I88 I et seq. (Supp., r95x); Fed. Housing Regulation (N.Y.C., I949), 24 Code Fed. Regs. c. 8 \$ 825.22 (I949).

4 Cf. Majen Realty Corp. v. Glotzer, 6r N.Y.S. $2 d$ I95 (N.Y. Munic. Ct., I946). See note 26 infra.

5 Cf. San Diego v. Van Winkle, 69 Cal. App. $2 d$ 237, $5_{5}^{8}$ P. 2 d 774 (r945).

6 "Yet it seems intolerable," says Judge Quinn, rather flamboyantly, "that the tenant, trapped between the burned-out shell of his home and the public emergency which prevented him from going to another, must cling to the naked possession of the uninhabitable and while waiting month after month, upon the dilly-dallying of his landlord in the work of repair, still remain liable, without redress from the inexorable accrual of the full rent." Johnson v. Pemberton, 197 N.Y. Misc. 739, 97 N.Y.S. 2d I53, I56 (N.Y. Munic. Ct., I950).

7299 N.Y. 70, 85 N.E. $2 d 869$ (I949). 
[M]echanical application of common-law rules will not promote reasonable decision in cases controlled by emergency rent legislation. ${ }^{8}$

If we are to say, with Judge Quinn, that various rent statutes have been passed "to free tenants from entrapment between the housing shortage and the imposition of intolerable housing conditions including the exaction of unconscionable rents," "then rent controls, to be effective, must include in their scope, among other things, the amount of rent, the terms of the lease, and the services rendered by the landlords. ${ }^{10}$ In the case of federal control, however, although the provisions are set out generally in the statutes and regulations issued pursuant to them, ${ }^{\text {II }}$ their precise application is often determined by state law. ${ }^{12}$ In such cases the effectiveness of rent control may well turn upon the application of the traditional rules. It is for this reason that Judge Fuld in the Finkelstein case, referring to the "cases controlled by emergency rent legislation," stated that mechanical application of common-law rules will not fulfill the intention of the federal acts. He appears, thus, to suggest that the courts should recognize that there is a housing shortage of emergency proportions and that in that area where the application of emergency rent legislation turns upon state common-law rules, the courts should exercise their judicial discretion in a spirit compatible with the purposes of the legislation. This approach would seem to be a reasonable way to fit tenancy law to national needs, since, without a judicial disposition to relax the common-law rules in cases "controlled" by emergency rent regislation, such legislation may often be doomed to be ineffective.

It is clear from prior decisions that Judge Fuld is not alone in holding this view. Moreover, in some instances cases relaxing the common-law rules have not depended upon emergency rent legislation. The formal legal technique commonly used by courts to justify suspension of the common-law rules in such cases is that of judicial notice. As early as 1938 a New York judge stated:

\footnotetext{
${ }^{8}$ Ibid., at 75 and 872 (italics added). See also Majen Realty Corp. v. Glotzer, 6I N.Y.S. 2d I95, I97 (N.Y. Munic. Ct., I946).

9 Johnson v. Pemberton, I 97 N.Y. Misc. 739, 743, 97 N.Y.S. 2 d I53, I 57 (N.Y. Munic. Ct., r950).

so See Willis, The Federal Housing and Rent Act of 1947, 47 Col. L. Rev. IIr8 (I947); Drach and DeBoice, O.P.A. Rent Control Procedure, 32 Ill. B.J. 47 (I943).

xI Since there have been so many separate rent acts and regulations issued thereunder, reference to specific acts is purposely kept at a minimum. For a detailed analysis of the federal rent statutes, see Mermin, An Analysis of Federal Rent-Control Enforcement Litigation, 2 Okla.L. Rev. 4 II (I949); Friedlander and Curreri, Rent Control, Federal, State, and Municipal (I948). See also Friedman, The Business and Commercial Rent Control Laws of New York (1948); Willis, The Federal Housing and Rent Act of 1947,47 Col. X. Rev. III8 (1947); Griffiths, Rent Procedure under the Emergency Price Control Act of 1942, 22 Mich. S.B.J. 375 (1943); Riggs, Landlord and Tenant, 24 N.Y.U.L.Q. Rev. I 201 (1949).

${ }_{22}$ For example, under the Housing and Rent Act of 1949,63 Stat. I8 (I946) as amended, 50 U.S.C.A. \& I88r (Supp., I95I); Fed. Housing Regulation (General), 24 Code Fed. Regs. c. 8, $\$ 825.6$ et seq. ( 1949 ), certain grounds must exist before eviction is justified-violation of a substantial obligation of tenancy, committing or permitting a nuisance, or owner seeks in good faith to recover possession of premises for his immediate and personal use. But state law is to determine precisely what is a violation of tenancy, etc.
} 
I am satisfied that there is an emergency housing shortage in low-rent apartments in the City of New York and I take judicial notice thereof. . . . Extreme hardship would be occasioned to this tenant and his family if I did not stay the warrant of dispossess. ....3

Here there was no applicable federal or state rent regulation, but under Section $\mathrm{r}_{436}$-a of the Civil Practice Act, ${ }^{14}$ a judge could stay the execution of an order dispossessing a holdover tenant in premises occupied for dwelling purposes provided that, among other things, the tenant had tried to secure other premises but could not. Later, New York courts reached similar decisions in two cases, one involving residential ${ }^{15}$ and the other commercial ${ }^{16}$ premises. In both cases, the courts felt that even though rent regulations justified the issuance of warrants of dispossess, the existence of the housing shortage justified the stay of the issuance.

Nor are such examples of the use of the technique of judicial notice limited to cases where state law. specifically allows a judge to exercise his discretion in applying traditional tenancy rules by staying, for example, the issuance of warrants of disposses. Thus, where a plaintiff sued for specific performance of a lease, the court took judicial notice of the fact that there was a shortage of such "bungalows." It followed, therefore, that the plaintiffs did not have an "adequate remedy at law to compensate them and their families for the loss of their summer at the Long Island Seashore" and were entitled to specific performance of the lease. ${ }^{17}$ Likewise, in Green Point Savings Bank v. Lefkowitz, ${ }^{18}$ the court used judicial notice of the housing shortage to justify staying the execution of an order putting the purchaser at a foreclosure sale into possession of premises occupied by the defendants whose rights to posseśsion under federal rent regulations were cut off at the foreclosure sale. The court stated that " $[t]$ he present application [of the Federal Rent Regulations], however, is addressed to the court's conscience." ${ }^{\prime 9}$

That the use of judicial notice of the housing shortage to justify suspension of traditional rules of landlord and tenant is a useful tool for fulfilling the purposes of rent control legislation is evident. By stating, for example, that "[i]t is

${ }^{23}$ Li-Mo Realty Corp. v. Davis, $x_{67}$ N.Y. Misc. 829,4 N.Y.S. $2 d 858,859$ (N.Y. Munic. Ct., 1938).

${ }^{14}$ N.Y. Civil Practice Act (Cahill, 1946).

${ }^{25}$ McLaughlin v. De Luca, r83 N.Y. Misc. 894, 50 N.Y.S. 2d 454 (N.Y. Munic. Ct., I944).

${ }^{26} 734$ Fifth Avenue Corp. v. Kent-Costikyan, 184 N.Y. Misc. 12, 54 N.Y.S. $2 d$ 770 (N.Y; Minic. Ct., I945). While Section I436-a of the Civil Practice Act applied only to "dwellings," the court found that under Section 6(3) of the New York Municipal Court Code it could grant a stay in the case of commercial premises.

${ }^{17}$ Kanner v. Enzler, 56 N.Y.S. 2 d 604, 605 (S. Ct., 1945).

${ }^{88}$ I84 N.Y. Misc. 716, 55 N.Y.S. 2d 8I9 (1945).

59 Ibid., at 717,820 . Compare the language in Boland v. Beebe, I86 N.Y. Misc. 616,620, 62 N.Y.S. 2d 8, I3 (I946): "It is well known that the housing situation in the city of Syracuse is critical to the point of emergency. Any court charged with the responsibility of applying these housing laws and regulations at this time must take judicial notice of the emergency and exercise discretion commensurate therewith." 
a matter of common knowledge that there is a great shortage of homes in [the] community at the present time [and] that eviction proceedings are constantly increasing," ${ }^{\prime 20}$ courts give themselves a public policy factor useful in deciding what constitutes an immediate compelling necessity on the part of the landlord to occupy the premises for himself, ${ }^{2 x}$ or a nuisance or violation of a substantial obligation of tenancy ${ }^{2 z}$ under the rent acts. Thus, the court in Majen Really Corp. v. Glotzera reached the conclusion that

[w]hile it is true that in order to sustain the defense of constructive eviction, there must be an abandonment of the premises ... that rule rests upon the reasoning that if the premises in fact were not fit for occupancy, the tenant would not have retained possession but would have moved elsewhere, and his remaining in the premises belies any claim that they were not fit or habitable. ${ }^{24}$

${ }_{20}$ Liberty National Bank v. Zimmerman, 333 Ill. App. 94, 104, 77 N.E. 2d 49, 54 (1947). The case presented the question of whether the tenant's daughter and the daughter's husband and child came within the meaning of "family." The court stated that "it would be highly inequitable to narrow the meaning of the word 'family' in cases like this instant one," implying that in some cases the meaning might be restricted. The existence of the housing shortage seemed to turn the scales. Cf. Park East Land Corp. v. Finkelstein, 299 N.Y. 70,85 N.E. $2 d$ 869 (I949) where the court admitted that, technically, the lease was violated when the widow of the deceased lessee remarried and moved out of the apartment leaving her son to live there with her new step-daughter and the latter's husband; but the violation was not of substantial character, particularly since the landlord had no extra burden and received the same rent. The court recognized the necessity for the "relaxation" of traditional rules of tenancy in times of housing shortages.

${ }^{27}$ See Boland v. Beebe, 186 N.Y. Misc. 6r6, 62 N.Y.S. 2d 8 (x946); cf. Clemente v. Finkelstein, 274 App. Div. 1069, 85 N.Y.S. 2d 638 (2d Dep't, 1949), where the court refused to grant a certificate of eviction because the compelling necessity was self-created.

23 See Matter of Park East Land Corp. v. Finkelstein, 299 N.Y. 70, 85 N.E. 2d 869 (r949); see also Lang v. Fienderson, $x_{47}$ Texas 353 , $21_{5}$ S.W. $2 d{ }_{5} 8_{5}$ (r948). There, the plaintiff, a tenant, sued the landlord for injuries caused when a heater exploded. The landlord claimed that the tenant was contributorily negligent and had assumed the risk because he had remained in the apartment after knowing of the defect. In saying that "[w]e cannot be certain that a reasonable person under the circumstances in evidence would have moved from the apartment," the court took judicial notice of the housing shortage. Ibid., at 358 and 587 . For use of judicial notice of the housing shortage in cases other than those involving landlord and tenant law; see Douds v. Local 24368, United Wire \& Metal Workers Union, 86 F. Supp. 542 (S.D.N.Y., I949); Salter v. Becker Roofing Co., 65 F. Supp. 633 (N.D. Ala., I946); John Hancock Mutual Life Ins. Co. v. Ford Motor Co., 322 Mich. 209, 33 N.W. 2d 763 (I948).

${ }^{3} 6$ I N.Y.S. 2 d r95 (N.Y. Munic. Ct., 1946).

24 Ibid., at I96. The court found that, where the local area office of the Office of Price Administration would be authorized to reduce the maximum rent for any diminution of services or facilities, the court could similarly make an allowance for diminished facilities and services accorded the tenant through the neglect of the landlord which constituted a statutory violation. (The statute violated imposed upon landlords a duty to keep multiple dwellings clean and in good repair, but did not provide for the lowering of rent. N.Y. Multiple Dwelling Law $\$ \$ 78,80$.) The court also found, on the basis of the housing shortage, "that because of the non-use and inability to use a portion of the premises, under present existing conditions, that will be considered $a$ surrender of possession of that portion constituting a partial constructive eviction. Ibid., at I97. See notes 2 and 5 supra. Had Judge Quinn in Johnson v. Pemberton chosen to reach this same result, presumably he could have done so. The landlord there had already been summoned 'to Magistrates' Court for a violation of his duty to repair under Section 78 of the Multiple Dwelling Law [and] had only reached the stage of pleading for 
Admitting that such a rule should prevail where a market of available dwelling accommodations exists, the court thought that such a rule should be "relaxed" where there is a housing shortage.

Obviously, the result of the exercise of judicial discretion in these cases achieves far different results than strict application of the old rules. In considering the desirability of these results it should be remembered that the courts have not taken it upon themselves to treat the traditional rules of landlord and tenant as obsolete 25 -rather, they seem to consider them as "suspended" for the duration of the housing shortage. In San Diego v. Van Winkle, ${ }^{26}$ for example, the court upheld the trial court's decision that the defendants should be enjoined from violating a city ordinance which prohibited multiple family dwellings in a single family zone, the enforcement of the injunction to be stayed, however, until after the "housing shortage." Of course, determination of the existence or nonexistence of a housing shortage may be difficult. The court in San Diego v. Van Winkle would probably take the position that the housing shortage ceased to exist when federal control ceased. Yet, as already shown, some courts have not confined the suspension of rules of landlord and tenant to cases governed by rent control acts. In view of the present federal rent control provisions for local option decontrol by states and municipalities, ${ }^{27}$ and the decisions that Congress' war power authorizes it not only to control rents during war, ${ }^{28}$ but also to control rents in attempting to remedy the consequences of upset economy and distorted social life which arise out of war, ${ }^{29}$ it is unlikely

further time in which to commence performance." I97 N.Y. Misc. 739, 741, 97 N.Y.S. 2 d I53, I55 (N.Y. Munic. Ct., I950).

By remaining in possession after he becomes aware of a nuisance amounting to constructive eviction, it appears that a tenant does not waive his right to terminate the lease if he relies on a promise that the evil will be remedied. See Marks v. Dellaglio, 56 App. Div. 299, 300, 67 N.Y.S. 736, 737 (Ist Dep't, 1900). There seems to be no reason why the courts could not reduce the rent during those months when the tenant was waiting for the landlord to repair, and where a housing shortage prevented him from going elsewhere. See Relaxation of Abandonment Requirement for Constructive Eviction, During Critical Housing Shortage, II Mo. L. Rev. $44^{\circ}$ (I946).

${ }_{25}$ Of course, many writers have taken the view that the traditional rules are simply obsolete. See Landlord and Tenant after OPA, I4 Univ. Chi.L. Rev. 243 (I947). That many states have recognized the "unfairness" of some common-law rules and have passed legislation to bring the law into accord with the "realities of the times" is well known. For example, the burden of repair has been shifted to the landlord in many states, a position that certainly seems to harmonize with the social and economic conditions of today. See Feuerstein and Shestak, Landlord and Tenant-The Statutory Duty to Repair, 45 Ill. L. Rev. 205 (I950).

${ }^{26} 69$ Cal. App. 2d 237, I58 P. 2d 774 (I945). See also Wilkins v. San Bernardino, 29 Cal. 2d 332, I75 P. 2d 542 (1946); cf. Majen Realty Corp. v. Glotzer, 6I N.Y.S. 2d I95 (N.Y. Munic. Ct., 1946$)$.

${ }_{27} 64$ Stat. 255 (1950), as amended, 50 U.S.C.A. App. $\$$ r894(j) (Supp., I95I).

${ }^{28}$ Bowles v. Willingham, $32 x$ U.S. $50_{3}$ (r944).

${ }^{29}$ Woods v. Benson Hotel Corp., 75 F. Supp. 743 (Minn., 1948). See Beinecke v. Terranova, 26 N.J. Misc. I5, 55 A. 2 d 658 (1947); Woods v. Miller Co., 333 U.S. I38 (I947); Woods v. Shoreline Cooperative Apartments, 84 F. Supp. 660 (N.D. Ill., I949). 
that many courts will reach the conclusion that the housing emergency is over, at least in the predictable future, ${ }^{30}$ simply because federal rent control may go by the board. "3x "A law depending upon the existence of an emergency or other certain state of facts to uphold it may cease to operate if the emergency ceases or the facts change even though valid when passed." 32 But the housing shortage has been in existence for a long time, and the prospects are that it will continue for many years to come. Nor is there reason to believe that the emergency which justifies congressional exercise of war powers will cease in the immediate future. ${ }^{33}$ In absence of state legislative action, it appears that the only way to fit tenancy law to national needs is through judicial action compatible with emergency rent legislation. Whether these decisions "suspending" common-law tenancy rules will have the weight of precedent after federal rent control ceases remains to be seen. As long as there is a housing shortage, it seems that they should.

\section{PRICE DISCRIMINATION IN GASOLINE MARKETING: THE DETROIT JOBBERS CASE}

Standard Oil Co. v. Federal Trade Commission, ${ }^{\mathrm{x}}$ with a long history and a flood of comment to its credit, recently gave the Supreme Court an opportunity to settle an important question of construction under Section 2 (b) of the Robinson-Patman Act. ${ }^{2}$ However, the case also presented interesting economic questions concerning price discrimination in gasoline marketing, questions which received little attention in the Court's opinions and which have not been treated fully elsewhere. This comment essays a fresh appraisal by way of a factual analysis of the market in question and a theoretical observation on price dis-

${ }^{30}$ See Peck v. Fink, 2 F. 2d 9 I2 (App. D.C., I924). The court relied upon a statement by Justice Holmes in Chastleton Corp. v. Sinclair, 264 U.S. 543, 549 (r924) that "if the question were only whether the statute is in force today, upon the facts that we judicially know we should be compelled to say that the law has ceased to operate," to hold that the rent act for the District of Columbia, 43 Stat. I20 (I924), was unconstitutional. See also Kahn v. Wall, 68 A. 2 d 862 (App. D.C., I949).

${ }^{3 x}$ The court in Li-Mo Realty Corp. v. Davis, I67 N.Y. Misc. 829,4 N.Y.S. $2 d 858$ (N.Y. Munic. Ct., 1938) relied upon the Report of the New York City Housing Authority, Jan. 25, 1937, and the City of New York Vacancy and Rent Survey as of January 1938 to satisfy itself that there was a housing shortage. Other courts could use similar means even though rent control had ceased.

${ }^{32}$ Chastleton Corp. v. Sinclair, 264 U.S. 543, 547 (I924), opinion of Justice Holmes who also stated that "[i]f about all that remains of war conditions is the increased cost of living, that is not in itself a justification of the act." Ibid., at 548 .

${ }^{33}$ While the present federal rent acts are based upon the war power of Congress, there are those who believe that other bases exist upon which the control of rents could be justified. See Landlord and Tenant after OPA, I4 Univ. Chi. L. Rev. 243 (I947) (housing affected with a public interest) and McCarthy, Aspects of Federal Rent Control, 3 I Corn. L.Q. 68 (I945) (use of monetary clause of the Constitution to invoke rent controls).

I 340 U.S. 23 I (I95I).

${ }^{2} 49$ Stat. $1_{526}$ (1936), $x_{5}$ U.S.C.A. $\$ I_{3}$ (I95I). 